\title{
W cieniu Olgi Hepnarovéj - totalitaryzm XX wieku w optyce czesko-polskich koprodukcji filmowych
}

\begin{abstract}
Streszczenie
Wspólne przedsięwzięcia polskiej i czeskiej kinematografii mają tradycję sięgającą lat trzydziestych ubiegłego stulecia. Jednak ich coraz częstsze przypadki, odnotowane po upadku komunizmu i zmianie ustroju w Europie Środkowej wytworzyły szczególny wariant filmowej współpracy - odwołania do bolesnego dziedzictwa związanego z XX-wiecznym totalitaryzmem. Artykuł omawia przypadek trzech filmów wyprodukowanych za pieniądze czeskie i polskie (z niewielką pomocą słowacką, francuską i izraelską) w ostatnim dziesięcioleciu: W cieniu reż. David Ondříček, Gorejq̨cy krzew reż. Agnieszka Holland i Ja, Olga Hepnarová reż. Tomáš Weibreb i Petr Kazda. Tekst odnosi się do wspólnych wyobrażeń, specyfiki narodowej traumy, wyjaśnia status poszczególnych artystów związanych z różnym doświadczeniem pokoleniowym. Wreszcie przynosi garść informacji o recepcji i miejscu omawianych obrazów w szeroko rozumianej kulturze.
\end{abstract}

\section{Słowa kluczowe:}

polska kinematografia, czeska kinematografia, koprodukcje, normalizacja, stalinizm, Praska Wiosna

\begin{abstract}
Collaborative endeavor of Polish and Czech cinematography has had a tradition dated back to the 1930s. However, their more and more frequent instances dated after the fall of communism and the change of political
\end{abstract}

1 Mariusz Guzek, Wydział Humanistyczny, Uniwersytet Kazimierza Wielkiego w Bydgoszczy, Polska, e-mail: mariusz.guzek@gmail.com, ORCID ID: https://orcid.org/0000-0002-2407-4499. 
system in Central Europe created a specific variant of cinematic cooperation - reference to distressing legacy attributable to 20th century totalitarianism. The article discusses the case of three films produced for Czech and Polish money (with a little Slovak, French and Israeli help) in the last decade: In The Shadow by David Ondříček, Burnish Bush by Agnieszka Holland and I, Olga Hepnarová by Tomáš Weibreb and Petr Kazda. It refers to the common perception and the specifics of the national trauma and explains the status of particular artists associated with different generational experience. Gradually, it brings a handful of information about the reception and place of the discussed images in broadly defined culture.

\section{Keywords:}

Polish cinematography, Czech cinematography, co-productions, normalization, stalinism, Prague Spring

Polsko-czeskie kontakty filmowe sięgają dwudziestolecia międzywojennego. Po 1945 roku w warunkach funkunkcjonowania obozu państw socjalistycznych nabrały one nowych wymiarów. Tworzyły je: wspólnota środkowoeuropejskich doświadczeń, podobna wrażliwość twórców i ten sam model produkcyjny wyznaczony upaństwowieniem przemysłu kinematograficznego (Skopal, 2014, s. 21$60)^{2}$. W wyznaczonych granicach postawały filmy wybitne: Zaklęte rewiry (Dvoji svět v hotelu Pacifik, 1975) w reż. Janusza Majewskiego i Ślady wilczych zębów (Zánik samoty Berhof, 1983) w reż. Jiřríego Svobody, jak i takie, o których lepiej zapomnieć, a wśród nich rej wodzi Pan Samochodzik i praskie tajemnice (Pražské tajemství, 1988) wypuszczony spod ręki Kazimierza Tarnasa.

W ostatnich dekadach koprodukcje polsko-czeskie i czesko-polskie (czasami z udziałem kinematografii słowackiej) stały się istotną częścią kulturowych projektów, odwołując się do rozwiązań gatunkowych charakterystycznych dla filmowej natury nad Wełtawą i Wisłą ${ }^{3}$, ale też do katalogu bolesnych spraw

${ }^{2}$ W oparciu o całkowicie nieznane materiały archiwalne wspólne inicjatywy telewizyjne w latach 1953-1989 omówił Jakub Jiřiště (Jiřiště 2018, s. 53-70).

3 Czeską specjalnością były np. kostiumowe bajki filmowe (pohádky), za mistrza których uważano autora popularnego serialu Arabela Václava Vorlíčka. W roku 1999 zrealizował on wspólnie z polskim studiem Oko-Film (oraz podmiotami ze Słowacji, Węgier, Niemiec i Francji) Króla sokołów na postawie opowiadania Sokoliar Tomáš słowackiego pisarza i działacza Matice slovenskej Jozefa Cígera Hronskégo. Jak oświadczył Vorlíček w opublikowanej niedawno biografii: „dzięki takiej współpracy mogłem nakręcić naprawdę królewski obraz. Za to jednak musiałem znaleźć w obsadzie miejsce dla polskich i francuskich aktorów. Jedynie Niemcy nie nalegali na udział swoich wykonawców” patrz: Macek 2017, s. 180. 
wynikających ze specyfiki XX wieku z jego totalitarną traumą na czele. Wspomnienia a nade wszystko rozliczenia z komunizmem, tworzyły specyficzny nurt refleksji. Swego czasu opisując polsko-czeskie kontakty filmowe na przełomie wieków wyodrębniłem trzy podstawowe warianty celuloidowej współpracy: koprodukcje z polską dominantą diegetyczną, koprodukcje z czeską dominantą diegetyczną i koprodukcje ze wspólną perspektywą diegetyczną (Guzek 2017, s. 103). Trzy analizowane przypadki, które tyczą doświadczenia totalitarnego (komunistycznego), reprezentują drugi wariant - ich akcja dzieje się w Czechosłowacji, a nawet w stołecznej Pradze (choć realizowane były również w polskich warunkach), wszystkich twórców łączy formacyjne doświadczenie związane z nadwełtawską kinematografią (choć nie wszyscy są Czechami), popularność zdobywały głównie w kinach Pragi, Brna i Ostrawy, a z mniejszym powodzeniem pokazywane były w Polsce. Bohaterowie tych filmów, niezależnie czy autentyczni, czy będący eksplikacją scenariuszowej koncepcji, wtopieni byli w aurę ważnych dla czechosłowackiej tożsamości wydarzeń (stalinizm, Praska Wiosna, normalizacja). Jednak bez polskiego udziału estetyczny i ideologiczny ich kształt byłyby zdecydowanie inny.

Najwcześniejszy z nich W cieniu (Ve stínu) zrealizowany w 2012 roku przez Davida Ondříčka (syna Miroslava Ondříčka, uznanego operatora filmów Lindsaya Andersona, Miloša Formana czy Janusza Majewskiego ${ }^{4}$ ) ubrany w konwencję noir, odwołuje się do mało znanego epizodu powojennej historii - reformy walutowej (měnová reforma) z 1953 roku. Początkowa intryga kryminalna - włamanie do kasy jednego ze stołecznych sklepów jubilerskich i prowadzone w tej śledztwo przez głównego protagonistę, kpt. Służby Bezpieczeństwa (Státní bezpečnost) Jaroslava Hakla (Ivan Trojan) powoli, acz nieuchronnie kieruje widza ku zakamarkom ówczesnego totalitarnego uniwersum. Hakl jest oficerem kryminalnym ze starej szkoły policyjnej, wierzącym w sprawiedliwość i uparcie do niej dążący - należy do odchodzącego porządku, a nowy kontestuje i dlatego system komunistyczny w okrutny sposób go unicestwia. Ondříček swój film zadedykował „ofiarom procesów politycznych z lat pięćdziesiątych i wszystkim, którzy mieli odwagę walczyć z reżimem” i dlatego bogato inkrustuje akcję stalinowską fakturą - bez-

${ }^{4}$ Miroslav Ondříček tak scharakteryzował filmowy status swojego syna: „z radością obserwuję sukcesy Davida. Potrafił zbudować sobie silną pozycję wśród młodych twórców zajmujących się wideoklipami i tym umocnił się w branży reklamowej. Powierzano mu najbardziej prestiżowe i najbardziej lukratywne projekty począwszy od czeskich banków na wielkich koncernach, jak Coca-Cola, kończąc. Stworzył dobrze działającą firmę produkcyjną i dzięki niej realizuje pełnometrażowe filmy. Tak więc Ondříčkovie nie wymrą ani jako ród, ani jako filmowcy i to mnie niezwykle raduje” (Ondříček, Šmídmajer 2011, s. 236). 
pieczniaccy oprawcy, antysemickie (ukryte pod retoryką antysyjonistyczną) intrygi, decyzyjny status Moskwy ${ }^{5}$, kryminalne ekscesy władzy ukazane są w sposób nie tylko przejmujący, ale i wiarygodny, choć „nie epatują pornografią totalitaryzmu” (Czerkawski 2013, s. 67). Kluczem do wyeksplikowania istoty powojennego czechosłowackiego komunizmu jest społeczna aura wytworzona przez wspomnianą wyżej reformę walutową, której władze z prezydentem republiki Antonínem Zápotockim na czele, aż do wprowadzenia jej w życie latem 1953 roku, konsekwentnie zaprzeczały (zj, j-knal 2012, s. 668-680). Później dla opanowania powszechnego niezadowolenia posłużyły się prowokacją rzekomo demaskującą praską gminę żydowską jako siedlisko agentów imperialistycznych i syjonistycznych.

David Ondříček kręci filmy długo - zaskakuje widza co kilka lat nową realizacją i tak też było tym razem. Pomysł podobno pochodził od ojca reżysera - Miroslava. Kiedy rozmawiali o tematach nieobecnych, starszy Ondříček nadmienił, że jeszcze nigdy nie wyjaśniono na ekranie mechanizmów reformy walutowej z 1953 roku, w wyniku której komuniści niemal zniszczyli klasę średnią - inteligencję (Jaremková 2012: 15). Od złożenia pierwszej eksplikacji do wprowadzenia na ekrany Ve stínu minęło sześć lat, przygotowano aż siedemnaście skryptów scenariuszowych, przez ostatnie pół roku zmieniając, korygując i uzupełniając diegetyczny porządek. Nawet przewidziana na luty 2012 roku premiera musiała poczekać do września. Na skutek sugestii amerykańskiego producenta i późniejszego dystrybutora Ehuda Bleiberga materiał skrócony został do 100-minutowego metrażu. W znaczący sposób uległa modyfikacji muzyka jednego z najlepszych czeskich kompozytorów filmowych - Jana P. Muchowa, któremu towarzyszył przy tworzeniu niektórych partii słowacki muzyk Michal Novinski (kilka lat później jedna z jego piosenek zostanie wykorzystana na ścieżki dźwiękowej Planu B. Kingi Dębskiej). Zadaniem czeskich krytyków opłaciło się to reżyserowi i jego ekipie.

„W cieniu wnosi promień światła do mroku czeskiego filmu. Ma atrakcyjną aurę retro-kryminału, ale z wyraźnym przesłaniem i prawdziwymi postaciami, a nie z figurkami błagającymi o akceptację widza” - czytamy na łamach popularnego dziennika „Mlada fronta DNES” (Spačílová 2012, s. 13).

Interesującą fabułę film zawdzięcza scenarzystom: Davidovi Ondříčkovi, Markowi Epsteinovi i Mishy Votrubie, ale faktura obrazu jest dziełem Adama Sikory - wybitnego operatora polskiego. Parę plenerów również zaimplantowano z Polski - „odnaleźliśmy tam miejsce, które wyglądało jakby żywcem wyjęte

${ }^{5}$ W jednej z polskich recenzji czytamy: „Mrukliwa obecność towarzysza Morozowa, który niedawno przybył z Moskwy i wydaje się tu prawdziwym władcą, ujawnia, że także i wśród funkcjonariuszy systemu panuje klimat lęku” (Jopkiewicz 2013, s. 92). 
z lat pięćdziesiątych, to było niezwykłe” - oświadczył reżyser po odwiedzeniu Wałbrzycha i niewielkiej dolnośląskiej gminy Walim, sławnej z poniemieckich podziemnych instalacji przemysłowych (jaz, 2012, s. 12). Wpisana w mroczną poetykę konwencji okazała się także sceneria Łodzi.

Obrazy Sikory w matowej otulinie, z filtrami maskującymi różnorodność praskich ulic odpowiadały bardziej konwencji noir niż sama koncepcja postaci. Nie sposób nie zgodzić się z Marcinem Adamczakiem, który wypunktował wszystkie konstrukcyjne odstępstwa od kanonu gatunku - podręcznikową uczciwość głównego bohatera kpt. Hakla, który pięć lat po „zwycięskim lutym”, kiedy to Komunistyczna Partia Czechosłowacji wyeliminowała polityczną konkurencję i rozpoczęła cykl pokazowych procesów z oskarżeniem Rudolfa Slánskiego na czele, wierzy w sprawiedliwe osądzenie sprawców, czy naiwną konstatację, „że syna można wychować pośmiertnie przekazując mu określone wartości”, na co wskazuje ostatnia scena, gdy nastoletni młody Hakl, broniąc słabszego kolegi, bezpośrednio kieruje wzrok w obiektyw kamery (Slovak 2016, s. 125). Bardziej istotna wydaje się jednak konstatacja świadcząca o transkulturowym czesko-polskim historiozoficznym przesłaniu:

Ondříček (przy udziale polskiego operatora oraz polskim wkładzie finansowym) prezentuje film bardzo nadwiślański, w którym liczy się beznadziejna nawet walka z przeważającymi potęgami i moralne nawet zwycięstwo, ofiara mająca przynieść korzyść przyszłym pokoleniom. Zauważmy, iż tego rodzaju bohaterowie znikają z polskiego kina, gdzie w fabułach polityczno-kryminalnych główni protagoniści ostatnimi laty zdecydowanie przegrywają, a o latach stalinowskich w konwencji kina noir w Polsce opowiada się głównie w stylu komediowym (vide: Rewers Lankosza), co ciekawie komplikuje przeciwstawienie kultury i kina rodzimego oraz naszych południowych sąsiadów (Adamczak 2013, s. 102-103).

Przywołanie dzieła Borysa Lankosza jest nie tylko oczywistą figurą stylistyczną, z uwagi na niemal monochromatyczną fakturę zdjęć Adama Sikory w W cieniu i Marcina Koszałki w Rewersie. Kompozycja zaproponowana przez pierwszego z nich została odnotowana przez wielu recenzentów, pisano m.in., że „dostraja on pojedyncze obrazy do ciemnych odcieni, a poszczególne postaci pozostawia w półmroku, by wydobyć z nich tajemniczość i skrywaną dwoistość” (Štefunková 2012, s. 26). Nadto kryminalna fabuła W cieniu i Rewersu, skrywająca początkowo polityczny kontekst, odwołuje się do doświadczenia wspólnego - reformy walutowej w Czechosłowacji 1953 i tzw. drugiej reformy walutowej w Polsce w roku 
1950. Były one nie tylko traumatycznym i jednocześnie opresyjnym działaniem, ale także pozostawały poza mitotwórczą semiotyką ustrojowej kontestacji. Przy budowaniu postkomunistycznego podglebia nie przywoływali ich ani Czesi, ani Polacy. Jednak zdaniem Ondříčka:

Początek lat pięćdziesiątych jest jednym z najbardziej mrocznych epizodów w historii Czechosłowacji. Komuniści umacniają swoją władzę, sowieccy doradcy uczestniczą w organizowaniu służby bezpieczeństwa. Ludzie są zdezorientowani i się boją. Deszcz, mroczne zakątki, częste wyłączenia prądu dopełniają atmosfery filmu noir (Štefunková, 2012, s. 26).

Obecność Adama Sikory w czeskiej przestrzeni filmowej nie ograniczyła się jedynie do autorstwa zdjęć $W$ cieniu. Trzy lata później został zaproszony do udziału w debiucie fabularnym Tomáša Weinreba ${ }^{6}$ i Petra Kazdy - Já, Olga Hepnarova. Polski wkład jest niebagatelny - to obok Sikory odtwarzająca tytułową postać Michalina Olszańska, ale także nakręcone plenery. Reżyserzy klimat peryferyjnej Pragi odnaleźli w okolicach Kłodzka, Nowej Rudy i Wrocławia (ul. Roosevelta, budynek Akademii Medycznej przy ul. Wrońskiego, Zakład Karny nr 1 przy ul. Kleczkowskiej). Zresztą Tomáš Weinreb skomentował to następująco:

Dość szybko doszliśmy do wniosku, że - nawet jeśli akcja filmu toczy się w Pradze - większość zdjęć będzie musiała powstać gdzie indziej, bo miasto to przez niemal czterdzieści lat zdążyło zmienić się nie do poznania. Na szczęście miejsca, które z powodzeniem mogły zagrać naszą stolicę z lat 70., znaleźliśmy w Nowej Rudzie i Wrocławiu (Czerkawski 2016, s. 63).

Sprawę Olgi Hepnarovej, ostatniej kobiety, na której wykonany został w Czechosłowacji wyrok śmierci, zrekonstruował znany dziennikarz śledczy Roman Cílek, który na podstawie protokołów sądowych, przeprowadzonych przez siebie wywiadów i notatek prasowych stworzył relację reporterską, dzięki której Kazda i Weinreb nakręcili swój film (Cílek 2010)․ Polskie tłumaczenie książki Cílka autorstwa Julii Różewicz, zatytułowane tak samo jak kinowy obraz, ukazało się

6 Tomáš Weinreb w 2009 roku nakręcił film dokumentalny Všechno je sračka (Wszystko to gówno), którego bohaterem był Miroslav David, partner Olgi Hepnarovej - w filmie Já, Olga Hepnarová kreował go Martin Péchlat.

7 Krótko przed premierą filmu w 2014 roku ukazała się kolejna wersja książki Cílka, zatytuło- 
nieco później i jego związek z premierą, na co wskazują zamieszczone kadry (fatalnej zresztą jakości), był wręcz organiczny (Cílek 2016). Na antynomiczne relacje między literacką rekonstrukcją przypadku Hepnarovéj a jej filmową reprezentacją, z czym nie sposób się nie zgodzić, zwrócił uwagę w jednej z nielicznych polskich recenzji Jakub Socha:

Książka Cílka jest polifoniczna i meandryczna. Mieszają się w niej różne płaszczyzny czasowe i różne głosy. Świadkowie snują własne historie, własną historię snuje Olga, własną narrator. Film to prymitywna biografistyka od kołyski aż po grób, nakręcona na czarno-białej taśmie, która służy chyba tylko temu, by ukryć biedną inscenizację (Socha 2017: 86).

22-letnia Olga Hepnarová (1951-1975), ewidentnie cierpiąca na zaburzenia osobowości, w lipcu 1973 roku rozjechała kilkanaście osób stojących na przystanku autobusowym przy alei Obrońców Pokoju (dziś nosi imię Milady Horakovéj), obok pl. Strossmayera na praskich Holešovicach, ośmioro poszkodowanych zginęło na miejscu lub zmarło w wyniku powypadkowych obrażeń. Film podpiera się ekstremalną, psychotyczną, sugestywną, niemal zdehumanizowaną kreacją Michaliny Olszańskiej (która wcześnie pokazała się z bardzo dobrej strony w Córkach dancingu [2015] Agnieszki Smoczyńskiej). Nie do przecenienia jest, że grała ona w języku czeskim. Krytycy, tacy jak Václav Votruba, nazwali jej interpretację tytułowej postaci oszałamiającą - „była makabryczna, niepokojąca, zimna, a jednocześnie ludzka i budząca współczucie” (Votruba 2016). Mirka Spačílová, wpływowa recenzentka popularnego dziennika „Mladá fronta DNES”, nie tylko pochwaliła Olszańską za „doskonały rodzaj aktorstwa”, ale także przywołała w tym kontekście czeską rolę innej polskiej wykonawczyni Karoliny Gruszki, która kilka lat wcześniej zagrała u boku Křyštofa Hádka rolę Mileny Jesenskiej w filmie Tomáša Mašína 3 sezony w piekle (3 sezóny v pekle, 2009) o młodości Egona Bondiego. Obie kreacje były jednocześnie „czarujące” i „dziwne”, sugerujące widzowi zarówno odrzucenie, jak i akceptację (Spačílová 2016, s. 16). Sama Michalina Olszańska, której udział był konsekwencją wygranego castingu (takie były założenia koprodukcyjne), o budowaniu postaci Hepnarovéj powiedziała:

Próbowałam, na ile to było możliwe, ją zrozumieć. Wyobraziłam sobie, że jest współczesną nastolatką, młodym, skrzywdzonym, odsuniętym od

wana Oprátka za osm mrtvých, z dopiskiem na okładce „nyní zfilmováno pod názvem Já, Olga Hepnarová” (Cílek, 2014). 
innych, cierpiącym człowiekiem, jakich spotykamy setki. Każdy ma jakiś ukryty problem, którego sam nie może rozwiązać, a pomoc z zewnątrz odrzuca. Im większy jest mur między nim a światem realnym, tym mniej szans na wydostanie się z tego. To moim zdaniem spotkało Olgę (Spačílová 2016, s. 16).

Czarno-biały świat wyłaniający się z monochromatycznych ujęć Sikory odwoływał się do doświadczenia czechosłowackiej normalizacji i polskiego stanu wojennego, a więc wizji, które utkwiły w pamięci Polaków i Czechów jako pozbawione barw i zbudowane na zasadniczych opozycjach psychologicznych, obyczajowych i politycznych. Transnarodowy charakter wspólnej realizacji, ukryty w znaczeniach diegetycznych, trudno było jednak oprzeć na brawurowej kreacji utalentowanej aktorki i znakomitych zdjęciach mistrza kamery. Te walory nie wystarczyły by uratować przedsięwzięcie. Kazda i Weinreb co chwila wpadali w narracyjne pułapki, tworząc chaotyczną, poplątaną i przede wszystkim mało czytelną opowieść z pogranicza psycho-thrillera i dramatu sądowego. Nasycenie filmu odważnymi scenami seksu lesbijskiego (głównie z udziałem Olszańskiej i Mariki Šoposkiej) rodziło ponadto oskarżenia o nazbyt oczywiste techniki pozyskiwania kinowej publiczności, choć w przestrzeni festiwalowej (o czym poniżej) zostały dobrze przyjęte.

Czeska krytyka filmowa była jednak dla obrazu Weinreba i Kazdy bardzo łaskawa. Piszący na łamach „Cinepur” Janis Prášil porównał go z Idq (2013) Pawła Pawlikowskiego, Białq wstążkq (Das Weisse Band - Eine deutsche Kindergeschichte, 2009) Michela Hanekego i „Słoniem” (Elephant, 2003) Gusa van Santa, a więc umieścił opowieść o Oldze Hepnarovéj w szerokiej perspektywie kina autorskiego i artystycznego (Prašíl 2016, s. 45). Taką ocenę nie tylko sugerowała dedykacja twórców dla Františka Vlačíla - jednej z największych indywidualności środkowoeuropejskiego kina poetyckiego, autora Małgorzaty córki Łazarza (Marketa Lazarová, 1967), czy sugestywny format zdjęć Sikory, ale także poszukiwanie wspólnego mianownika między tradycją czeskiego kina a jego obecną kondycją. W wydaniu anglojęzycznym publikowanego od 2008 roku kwartalnika „Film a doba” ukazał się artykuł Ondřeja Pavlíka. Powołując się na opinię wyrażoną na łamach wpływowego magazynu „The Hollywood Reporter”, uznał on, iż Já, Olga Hepnarová adresowany jest do takiej samej atrhousowej publiczności jak Ida Pawlikowskiego. Do tego dołożył jeszcze obecną w światowym kinie niezależnym tematykę queer, co sprawdziło się podczas pokazów Panoramy na Berlinale 2016, gdzie film miał swoją międzynarodową premierę. Jednak w kontekście wpisywania filmu w perspektywę europejską zauważył, że: 
Paradoksalnym faktem jest to, że wymarzony przykład konkurencyjnego dla innych europejskich obrazów filmu jest dramatem kobiety w ciężarówce „Praga”, zaś jego materia ściśle związana z historią czeską (Pavlík 2017, s. $9-10)^{8}$.

Luboš Ptáček, analizując estetykę obecną w czeskich produkcjach filmowych opowiadających o Czechosłowacji po inwazji w 1968 roku, a nakręconych już w XXI wieku, posłużył się w przypadku obrazu Ja, Olga Hepnarová jeszcze jedną konotacją. Napisał, że w filmie nie zaprezentowano argumentów antyreżimowych, od których roi się w innych fabułach rozgrywających się w warunkach normalizacji, a nawet kara śmierci i jej wykonanie zostały ukazane bez ideologicznej podpórki, jako oskarżenie komunistycznej władzy. Takie ujęcie lokuje dzieło Weinreba i Kazdy w porządku głębokiego uniwersalnego humanizmu, którego niedościgły wzorzec stworzył Krzysztof Kieślowski w Krótkim filmie o zabijaniu (Ptáček 2016: 95).

Życie dopisało jednak całkiem nieoczekiwany epilog - 6 czerwca 2016 roku film pod tytułem Moi, Olga rozpoczął swoją ekranową egzystencję we Francji. Jednak po zamachu dokonanym 14 lipca w Nicei przez tunezyjskiego terrorystę Mohameda Lahouaej-Bouhlela, w wyniku którego zginęło 87 osób, projekcje zostały odwołane. Podobny los spotkał także Dzień Bastylii wyreżyserowany przez Jamesa Watkinsa, który w jeszcze bardziej oczywisty sposób ewokował społeczne, traumatyczne konotacje (Baret 2016).

Wypowiedzią filmową o wyjątkowym charakterze miała być opowieść, której scenariusz przygotował młody, ale posiadający doskonałe przygotowanie merytoryczne, czeski filmowiec Štěpán Hulík . Wydarzeniem, do którego odwoływał się jego skrypt, była tzw. palachiada - cykl wydarzeń, który nastąpił po dokonaniu na placu Wacława w Pradze 19 stycznia 1969 roku samospalenia przez studenta Uniwersytetu Karola Jána Palacha w proteście przeciwko inwazji wojsk Układu Warszawskiego. Czyn, który obecnie oceniany jest w kategoriach tożsamościowych mitów postkomunistycznego czeskiego społeczeństwa, doprowadził do

${ }^{8}$ Pierwotnie ten tekst ukazał się w wydaniu z 26 maja 2016 roku internetowego portalu prowadzonego przez Národní filmový archiv „Revue Filmového přehledu” pod oryginalnym tytułem Jak Olga Hepnarová v pragovce objela svět (Prašíl 2016).

9 Štěpán Hulík jest absolwentem filmoznawstwa na Uniwersytecie Karola w Pradze oraz scenariopisarstwa i dramaturgii na FAMU. Obok przedsięwzięć realizacyjnych (napisał scenariusz do wyreżyserowanego przez Alice Nellis serialu Pustkowie/ Pustina i współpracował przy montażu serialu telewizyjnego o latach normalizacji Těžká léla československého filmu) napisał solidną naukową monografię o czechosłowackiej kinematografii w początkach normalizacji (Hulík 2011). 
rzeczywistej likwidacji dorobku Praskiej Wiosny i przyniósł opresyjną normalizację. Hulík wraz z jednym z producentów -Tomášem Hrubym - odwiedzili w Warszawie Agnieszkę Holland i namówili ją, by podjęła się reżyserii miniserialu Gorejący krzew (Hoříčí keř, 2013), złożonego z trzech półtoragodzinnych odcinków. Jak wspomniałem, punktem wyjścia było zdarzenie, które uformowało jedną z najważniejszych legend czechosłowackiej kontestacji - samospalenie Jána Palacha, ale właściwą bohaterką miniserialu jest mec. Dagmar Burešová (świetna rola Słowaczki Táňy Pauhofovej), która w imieniu rodziny Palachów prowadziła sprawę przeciwko posłowi KSČ Vilémovi Novému o znieważenie pamięci zmarłego studenta.

Tadeusz Lubelski wykorzystał interesującą propozycję metodologiczną zaczerpniętą od irańskiego medioznawcy Hamida Naficy’ego, a zastosowaną wcześniej przez Elżbietę Ostrowską dla opisu kina Agnieszki Holland, aby pokazać czym na tle całej „nomadycznej” twórczości reżyserki jest Gorejący krzew. Owa propozycja metodologiczna, czyli wyodrębnienie dla celuloidowych tułaczy „filmów z akcentem”, w których zarówno twórcy, jak i ich filmy ukazują nie tylko odmienność, ale i obcość (złe samopoczucie) wobec kultury dominującej, świetnie sprawdzała się w przypadku Agnieszki Holland do... momentu pojawienia się Gorejącego krzewu. Ten bowiem - zdaniem Tadeusza Lubelskiego - jest pozbawiony akcentu:

to film całkowicie czeski, wyprodukowany przez samych Czechów i mówiony wyłącznie biegłą czeszczyzną. Pozostaje transnarodowy, ponieważ jego reżyserką (...) jest Polka, choć Polka, jak wielu Polaków i wiele Polek, o skomplikowanej tożsamości (Lubelski 2017: 288-289).

Tę skomplikowaną tożsamość Agnieszki Holland i jej pokolenia ukazuje zrealizowany przez Krystynę Krauze i Jacka Petryckiego dokument Powrót Agnieszki H. (Návrat Agnieszký H., 2013), rozgrywający się w dwóch przestrzeniach czasowych - roku premiery Gorejq̨cego krzewu, kiedy to reżyserka odwiedziła Pragę by uczestniczyć w otwarciu wystawy poświęconej filmowi, oraz kilku miesiącach na przełomie lat 1968/1969, o których film opowiada, a które ją i jej przyjaciół uformowały. Uważam, że Powrót Agnieszki H. i Gorejący krzew należy oglądać równolegle - układają się one nie w fabularno-dokumentalny dyptyk, ale raczej w traktat biograficzny z bogatym aparatem źródłowym. Ponad godzinny polsko-czeski film dokumentalny pokazuje coś więcej niż „obrazki z wystawy” związanej z premierą Gorejqcego krzewu, którą odwiedziło troje niegdysiejszych studentów praskiej szkoły filmowej FAMU - Agnieszka H., Andrzej Zajączkowski i Andrzej J. Koszyk. To łobuzerska narracja, która przechodzi w pewnym momen- 
cie w rozliczenie całego życia, które zostało zdeterminowane przez młodzieńcze dotknięcie Praskiej Wiosny. Początkowo rewolucjoniści, trochę poszukujący przygody, trochę tożsamości, później więźniowie i uciekinierzy - nigdy się z tego doświadczenia nie wyzwolili. Lektura Powrotu Agnieszki H. to nie tylko wyjaśnienie skąd w roli Libušy Palachovej wzięła się Jaroslava Pokorná, ale także czym była aura pierwszych dni po inwazji, co dla przedstawicieli związku studentów znaczyły koncerty Karela Kryla (notabene pierwszy, niezachowany niestety, został zarejestrowany przez Zajączkowskiego) i, jak Pochodnia nr 1 (Pochoden̆ číslo jedna), czyli Ján Palach, poprzez swój czyn stał się punktem odniesienia dla wielu kontestacyjnych legend. Ten źródłowy charakter zebranej przez Krystynę Krauze dokumentacji, autorki od wielu lat tworzącej transnarodowe projekty niefikcjonalne (Nasz Vaszek. O sile bezsilnych/ Náš Vašek. O moci bezmocných, 2013, Braciszek Karel/ Bratříček Karel, 2016), nazwany został przez Jakuba Jiřrš̌tě w relacji z XVIII-tego Międzynarodowego Festiwalu Filmowego w Jihlavie „ukazaniem korzeni wewnętrznej siły światowej sławy reżyserki” (Jiřiště 2013).

Agnieszka Holland przypomniała o swoim filmie i jego pozaekranowym kontekście pod koniec 2017 roku, kiedy to w brneńskim miesięczniku literackim „Host” opublikowany został blok tekstów poświęconych Piotrowi Szczęsnemu - „Szaremu Człowiekowi”, który w Warszawie w proteście przeciwko łamaniu konstytucji i niszczeniu demokracji dokonał samospalenia. Powiązała postawy „Szarego Człowieka” i Jána Palacha, pisząc o determinacji, poświęceniu, a przede wszystkim braku zgody na milczenie o tym, co się stało (Hollandová 2017: 16-19) ${ }^{10}$. Wracała zresztą do tego wielokrotnie, również w kontekście swoich wcześniejszych filmów, takich jak Gorq̨czka (1981), który opowiadał, na podstawie prozy Andrzeja Struga, o rewolucji 1905 roku:

Prezentowane w „Gorączce” postawy są dziedzictwem mojego młodzieńczego doświadczenia. Widziałam w czeskim społeczeństwie wybuch entuzjazmu i wraz z nim czułam, że wolność jest w zasięgu ręki, i że jest świętem. To święto zostało brutalnie przerwane; jego klęska zakładała konieczność oporu, i to takiego, który - jak w przypadku Jana Palacha - czy właśnie Piotra Szczęsnego - wymaga skrajnych poświęceń. Po 1969 roku w Czechach zaczęła się konformizacja społeczeństwa, przez władze komunistyczne nazywana normalizacją. To Orwellowski termin, który zakłada, że ludzie dostosowują się do kłamstwa i strachu. Kiedy śledziłam i obserwowałam proces normalizacji,

10 Pierwotnie artykuł ukazał się na stronie internetowej (Holland 2017), a także w tygodniku „Polityka” (Holland 2017a, s. 86-88). 
byłam młoda i zaangażowana. Stało się to dla mnie granicznym doświadczeniem - widziałam na własne oczy, jak rzadkie są jednostki gotowe walczyć za każdą cenę (Serdiukow 2018: 32).

Nie zostawił natomiast na Gorejq̨cym krzewie suchej nitki Jan Čulík, lektor literatury czeskiej z Uniwersytetu w Glasgow, emigrant i dość sumienny obserwator nadwełtawskiej kinematografii ostatnich dekad, autor opasłego dzieła o filmach czeskich ostatnich dwóch dekad (Čulík, 2007), od kilkunastu lat prowadzący internetowy felieton „Britské listy”. Jego zdaniem film jest „powierzchowny, głupkowaty, manipulujący uczuciami widzów, a przede wszystkim nudny”, zaś scenarzysta był zbyt młody, by nakreślić bardziej skomplikowane postawy ludzi sprzed 60 lat. Čulík wylicza całą listę niekonsekwencji faktograficznych, ale najważniejsze oskarżenie filmu brzmi:

Przeraża mnie, że poziom kultury w Czechach spadł tak nisko, że ten gniot z powodów czysto ideologicznych niektórzy pod niebo wychwalają. Śmierć i pogrzeb Jána Palacha miały miejsce kiedy kończyłem szesnaście lat. To rzeczywiście odległy czas, niemniej zapamiętałem, że było to doświadczenie bardzo głębokie i wielostronne, czego nie można powiedzieć o tym tandetnym, nieznośnym dla widzów, złym filmie (Čulik 2014).

Čulík jest w swej krytycznej ocenie odosobniony. Takie radykalne spojrzenie jest jednak ważnym głosem w dyskusji, który należy uwzględnić, choć razi odrzucenie przez niego tzw. nowej wrażliwości, w ramach której mieści się przywoływanie wiedzy o epoce, ale z alternatywnymi sposobami jej odczytania, co np. zaprezentował w ubiegłym sezonie Julius Ševčík, realizując Masaryka z Karlem Rodenem w roli tytułowej.

W Polsce Gorejq̨cy krzew pokazywany był przede wszystkim w programach telewizyjnych producenta - HBO, ale wywołał bardzo ciekawą dyskusję na łamach prasy branżowej, a jeszcze w trakcie realizacji ukazał się duży tekst Mariusza Szczygła tłumaczący konteksty diegetycznego porządku (Szczygieł 2012, s. $54-55)$.

Jest sporo wspólnych przestrzeni między omówionymi czesko-polskimi produkcjami. Na jedną z nich zwrócił uwagę Jacek Szczerba, pisząc o filmie W cieniu Davida Ondř́čcka. To narodowe charaktery, układające się w katalog stereotypów, które z jednej strony pozwalają wbijać się w dumę Polakom i lekceważyć Czechów, których bitność rzekomo skończyła się po wojnach husyckich i klęsce pod Białą Górą, Czechom zaś pokazywać bezsens tromtadrackiego heroizmu Polaków 
i ironiczny status środkowoeuropejskiej historii, a z drugiej strony uniemożliwiają transnarodowe zrozumienie (na pewno nie porozumienie) między nami. Kinematografie polska i czeska skutecznie petryfikowały ten stan rzeczy:

Teraz się to jednak zmienia. Jakby młodym Czechom uwierała ta szwejkowska gęba. Propagują aktywność, opór. Dobrym przykładem tego jest Štěpán Hulík, dwudziestokilkuletni reżyser świetnego serialu HBO Gorejq̨cy krzew Agnieszki Holland. (...) Czy rzeczywiście oglądamy w kinie nową twarz Czechów, czy może tylko chwilowy makijaż (Szczerba 2013, s. 15).

\section{Bibliografia}

Adamczak, M. (2013). Dwa ćwiczenia stylistyczne. Odra, 9, s. 102-103.

Cílek, R. (2014). Oprátka za osm mrtvých. Praha: Marie Tum.

Cílek, R. (2016). Ja, Olga Hepnarová. Tłum. J. Różewicz. Wrocław: Wydawnictwo Afera.

Cílek, R. (2010). Olga Hepnarová. Zabíjela, protože neuměla žít. Praha: Nakladatelství XYZ.

Čulík, J. (2007). Jací jsme: Česká společnost v hraném filmu devadesátých a nultých let. Brno: Host.

Čulík, J. (2014). Hořící keř je neuveřitelně slabý film. Pobrane z: https://www.blisty.cz/ art/71956-i-horici-ker-i-je-neuveritelne-slaby-film.html.

Czerkawski, P. (2013). W cieniu. Film, 6, s. 67.

Czerkawski, P. (2016). Niezgoda na zapomnienie. Rozmowa z Tomašem Weinrebem. Kino, 6, s. 62-63.

Guzek, M. (2017). Polsko-czeskie inicjatywy filmowe na przełomie wieków. W: A. Szczepańska-Dudziak (red.), Polsko-czeskie kontakty dyplomatyczne, gospodarcze i kulturalne w XX-XXI wieku (s. 87-103). Szczecin: volumina.pl Daniel Krzanowski.

Holland, A. (2017). Ogień niszczy, ale też oświetla - jako gniew. Pobrane z: https://oko. press/agnieszka-holland-o-samospaleniu-piotra-ogien-niszczy-tez-oswietla-gniew/.

Holland, A. (2017a). Ogień niszczy, ale też oświetla. Polityka, 43, s. 86-88.

Hollandová, A. (2017). Oheňničí, ale i osvětluje - jak hněv. Host, 9, s. 16-19.

Hulík, Š. (2011). Kinematografie zapomnění. Počátky normalizace ve Filmovém studiu Barrandov (1968-1973). Praha: Academia.

Jaremková, M. (2012). Za tieňomtieň. Film sk, 9, s. 15.

Jaz (2012). Video: Střichalo se, změnila se hudba. Detektivka Ve stínu je hotová. Mladá fronta DNES, , s. 12.

Jiřiště, J. (2013). Portréty na vícero způsobů: sobotnií jihlavská sklizeň. Pobrane z: http:// www.indiefilm.cz/2013/10/28/portrety-na-vicero-zpusobu-sobotni-jihlavska-sklizen/.

Jiřiště, J. (2018). Rozwój współpracy koprodukcyjnej między telewizją czechosłowacką i polską w cieniu socjalistycznego internacjonalizmu w latach 1953-1989. W: E. Ciszewska, M. Góralik (red.). Polsko-czeskie i polsko-słowackie kontakty filmowe (s. 53-70). Łódź: Wydawnictwo Uniwersytetu Łódzkiego. 
Jopkiewicz, T. (2013). W cieniu. Kino, 9, s. 92.

Lubelski, T. (2017). Obrona przed bezdomnością? Gorejacy krzew - czeski film polskiej reżyserki. W: S. Jagielski, M. Podsiadło (red.). Kino polskie jako kino transnarodowe (s. 287-299). Kraków: Towarzystwo Autorów i Wydawców Prac Naukowych Universitas.

Macek, P. (2017). Václav Vorlíček. Pane, vy jste režisér. Praha: Ikar.

Ondříček, M., Šmídmajer, M. (2011). Tudy jenom procházíme. Praha: Nakladatelství XYZ. Pavlík, O. (2017). How Olga Hepnarová Traveled the World in a Praga Track. Film a doba. Special English Issue, 1, s. 8-11.

Prášíl, J. (2016). Já, Olga Hepnarová. Deník, dokument, rekonstrukce. Cinepur, 108, s. 42. Ptáček, L. (2016). Současná ideologie ve filmech o normalizacji natočených po roce 2000 v pohledu estetického historismu. W: L. Ptáček, P. Kopal (red.). Film a dějiny 6. Postkomunismus. Proměny českéh ohistorického filmu po roce 1989 (s. 69-104). Praha: Václav Žák - Casablanca, Ústav pro studium totalitníchrežimů.

Serdiukow, A. (2018). Ciekawiej dziś mówić o świecie niż o kinie. Rozmowa z Agnieszką Holland. Magazyn Filmowy SFP, 11 (87), s. 30-37.

Skopal, P. (2014). Filmová kultura severního trojúhelníku. Filmy, kina a diváci českých zemí, NDR a Polska 1945-1970. Brno: Host.

Slovák, M. (2016). Minulost jako kinematografická pastiš: Normal, Protektor, Vestinu. W: L. Ptáček, P. Kopal (red.). Film a dějiny 6. Postkomunismus. Proměny českého historického filmu po roce 1989 (s. 105-127). Praha: Václav Žák - Casablanca, Ústav pro studium totalitní chrežimů.

Socha, J. (2017). Ja, Olga Hepnarová. Kino, 1, s. 86.

Spáčilová, M. (2012). Film Ve stínu vnáší do soumraku českého filmu paprstek světla. Mlada fronta DNES, nr 256, s. 13

Spačílová, M. (2016). Recenze: Já, Olga Hepnarová. Osamělá lesba, až potom vražedkyně. Mlada fronta DNES, 78, s. 16.

Spačílova, T. (2016). Rozhovor. Hepnarovou jsme si vyrobili sami. Reflex, 15, s. 36-41.

Štefunková, Z. (2012). Vysokáhra v temných farbach. Film.sk, 10, s. 26-27.

Szczerba, J. (2013). Czarny czeski film. Bez kufla piwa, ale z szansą na Oscara. Gazeta Wyborcza, 142, s. 15.

Szczygieł, M. (2012). Krzew gorejący. Agnieszka Holland o Janie Palachu w Pradze. Filmowy Magazyn do Czytania, 1, s. 44-45.

Votruba, V. (2016). Recenze: Český film se může pochlubit dalším pokładem. Má název Já, Olga Hepnarová. Pobrane z: https://www.budejckadrbna.cz/zpravy/kultura/11389-recenze-cesky-film-se-muze-pochlubit-dalsim-pokladem-ma-nazev-ja-olga-hepnarova. html.

zj [Zdeněk Jirásek], j-kna [Jiři Knapík], (2012). Peněžní reforma. W: J. Knapik, M. Franc (red.), Průvodce kulturním děním a životním stylem v českých zemích II (s. 668-670). Praha: Academia. 